\title{
PERAN MASYARAKAT TIONGHOA TERHADAP PERKEMBANGAN KAWASAN HERITAGE DI KOTA LASEM, KABUPATEN REMBANG
}

\author{
Rohman Eko Santoso*, Suzanna Ratih Sari, Raden Siti Rukayah \\ *) Corresponding author email : rohmanekosantoso@gmail.com \\ Magister Arsitektur, Fakultas Arsitektur, Universitas Diponegoro
}

\begin{tabular}{l} 
Article info \\
MODUL vol 20 no 2, issues period 2020 \\
\hline Doi $\quad: 10.14710 /$ mdl.20.2.2020.84-97 \\
Received $: 29$ september 2019 \\
Revised $: 24$ januari 2020 \\
Accepted $: 23$ juni 2020
\end{tabular}

\begin{abstract}
Abstrak
Perkembangan kota lasem identik dengan istilah little china town, sehingga kebanyakan peneliti lebih fokus terhadap bangunan pecinan. Memang dalam peninggalan yang masih terlihat sampai dengan saat ini adalah bangunan-bangunan rumah tinggal dengan gaya china kuno dan klenteng-klenteng kuno yang masih utuh atau sama dengan bentuk aslinya. Sehingga sangat mendominasi kawasan Kota Lasem sebagai komplek permukiman pecinan terbesar di Jawa Tengah Khususnya. Perubahan tipologi dan morfologi maupun pengaruh bangunan Tionghoa sangat menarik untuk dilakukan penelitian yang sangat mendalam, karena sangat berperan besar terhadap kontribusi Kota Lasem. Betapa besar peran masyarakat Tionghoa selain berperan sebagai masyarakat yang melestarikan bangunan tetapi luasan dan sebaran permukiman maupun prasarana lainnya sangat kental dan berpengaruh sekali di Kota Lasem.
\end{abstract}

Kata Kunci: Tionghoa; Lasem; pecinan, heritage

\section{PENDAHULUAN}

Penelitian ini berjudul Peran Masyarakat Tionghoa Terhadap Perkembangan Kawasan Heritage Di Kota Lasem, Kabupaten Rembang. Berbagai review studi dan penelitian terkait Kota Lasem telah banyak memberikan informasi dan menunjukan bahwa Kota Lasem lebih didominasi bangunan pecinan, sehingga dalam peraturan pemerintah daerah menetapkan sebagai

Rohman Santoso, Suzanna Ratih Sari, Raden Siti Rukayah kawasan heritage atau kawasan kota pusaka. Berkaitan dengan sejarah yang ada, perkembangan Kota Lasem tidak terlepas dari peran masyarakat Tionghoa yang berpindah tempat tinggal pada tahun 1740 .

Saat ini Lasem sudah ditetapkan sebagai kawasan kota Pusaka oleh pemerintah pusat sehingga perlu dilakukan kajian-kajian yang lebih mendalam terkait potensi, permasalahan dan pengembangan di Kota Lasem. Penelitian ini bertujuan untuk mengkaji perkembangan permukiman dan kawasan heritage. Kawasan Heritage Kota Lasem dipilih karena merupakan objek penelitian yang memiliki banyak fenomena yang dibahas salah satunya pada hunian yang masih bertahan terhadap perubahan tampak maupun fungsi ruang.

\section{Rumusan Masalah}

Rumusan masalah yang dibahas dalam penelitian ini adalah sebagai berikut:

- Bagaimana awal mula masuknya masyarakat Tiong Hoa?

- Seberapa besar persebaran luasan kawasan permukiman dan bangunan bercirikan Tiong Hoa?

\section{Tujuan}

Penelitian ini bertujuan menganalisis seberapa luas permukiman dan pelestarian bangunan heritage dipermukiman pecinan di Kota Lasem.

\section{TINJUAN PUSTAKA}

Permukiman (Setiawan et al., 2017) mengandung dua arti kata berbeda yaitu isi dan wadah yang ditinjau dari struktur kata permukiman, yang mana permukiman harus memberikan rasa nyaman bagi manusia di dalamnya. Sifat dan karakter permukiman lebih komplek karena mencakup batasan ruang lingkup dan luasan yang lebih besar.

Permukiman menurut (Undang-Undang No. 1

Tahun 2011 Tentang Perumahan dan Kawasan 
Permukiman, 2011) adalah bagian dari lingkungan hunian yang terdiri atas lebih dari satu satuan perumahan yang mempunyai prasarana, sarana, utilitas umum, serta mempunyai penunjang kegiatan fungsi lain di kawasan perkotaan atau kawasan perdesaan.

Kawasan pecinan menurut (Fatimah, 2014) merupakan suatu wilayah/kawasan yang di dalamnya dihuni oleh mayoritas orang Tionghoa/keturunan Cina, pada umumnya terbentuk karena faktor sosial dengan hidup secara berkelompok. Kawasan pecinan dapat dilihat pada bagian kota dari segi penduduk, bentuk hunian, tatanan sosial serta suasana lingkungan memiliki ciri khas pertumbuhan kota berakar secara historis dari kebudayaan cina

Sedangkan pecinan menurut (Rudiansyah, 2014) adalah kawasan permukiman orang-orang Tionghoa yang tinggal di daerah perkotaan dan cenderung memiliki hidup secara berkelompok.

Permukiman pecinan menurut (Hendraswati et al., 2012) merupakan sebuah kawasan pecinan yang terbentuk dari adaptasi kosmologi cina terhadap kondisi geografis lokasi dan interaksi budaya bangsa Indonesia. Kehidupan para etnis cina membentuk struktur dasar zona ekonomi kota yang terdiri dari pasar, gudang, tempat usaha dan pelabuhan serta menjadi permukiman multietnik yang memebentuk inti kota bersama dengan elemen primer lain.

Heritage menurut (Sujana, 2017) merupakan warisan budaya yang berupa kebendaan (tangible) seperti bangunan, peralatan dan kerajinan tangan, atau tidak berwujud kebendaan (intengible) seperti norma. Sedangkan Bangunan heritage/bersejarah menurut (Runa, 2016) merupakan wujud fisik konstruksi yang memiliki nilai-nilai signifikan (penting dan asli) yang dapat dipertanggungjawabkan dari sudut waktu, langgam, keindahan, fungsi, kejadian atau peristiwa, dan keunikan, baik yang berarsitektur ataupun tidak berarsitektur.

Kawasan heritage menurut (Kartika et al., 2017) memiliki nilai sejarah tinggi dengan keunikan serta membentuk karakter dari perkembangan fisik sebuah kota. Sedangkan Kawasan heritage menurut (Christy \& Setyawan, 2016) merupakan kawasan yang memiliki perwujudan nilai-nilai budaya yang membentuk karakter sebagai jiwa dan perwujudan identitas suatu wilayah.

\section{Sejarah}

Sejarah Lasem menurut Pratiwo (2010) sebelum abad ke-20. Orang Tionghoa pertama kali mendarat dan masuk ke lasem pada abad 13, pada waktu itu belanda belum menjajah tanah jawa. Bahkan menurut cerita dan sejarah sebelum Cheng Ho sampai di Sungai Garang. Pembangunan permukiman berada disebelah timur sungai lasem sekitar abad 15, ditandai oleh pelabuhan untuk tempat berdagang (Gambar 1). Pada sebelah utara permukiman merupakan tambak, sawah dan pantai. Pada sebelah timur merupakan lahan kering dan bukit terjal sehingga mirip tembok benteng. Di selatan adalah sawah dan hutan jati sampai jauh ke pedalaman. Di sebelah barat menyeberangi sungai tempat pembuatan garam. Kota Lasem dikuasai oleh Bupati yang merupakan kepala pemerintahan di bawah Kerajaan Majapahit. Daerah kekuasaan bupati kurang lebih sekitar $10 \mathrm{Km}$ di sepanjang pantai dan membentang $4 \mathrm{~km}$ ke kearah selatan (Gambar 1). Pusat pemerintahan dan politik daerah ini adalah rumah bupati, terletak di sebelah selatan permukiman Tionghoa atau pecinan. Di depannya ada sebuah alun-alun yang di sisinya ada sebuah jalan penghubung ke pedalaman, jalan ini sekarang dinamai Jalan Jatirogo.

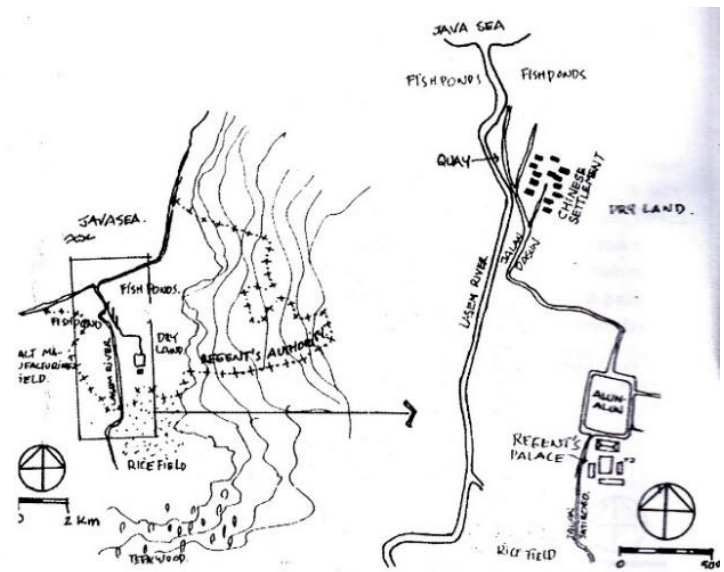

Gambar 1. Lasem abad ke-15 (Tahun 1513) Daerah di bawah wewenang Bupati, Pecinan, Rumah Bupati dan Alun-alun (Pratiwo, 2010)

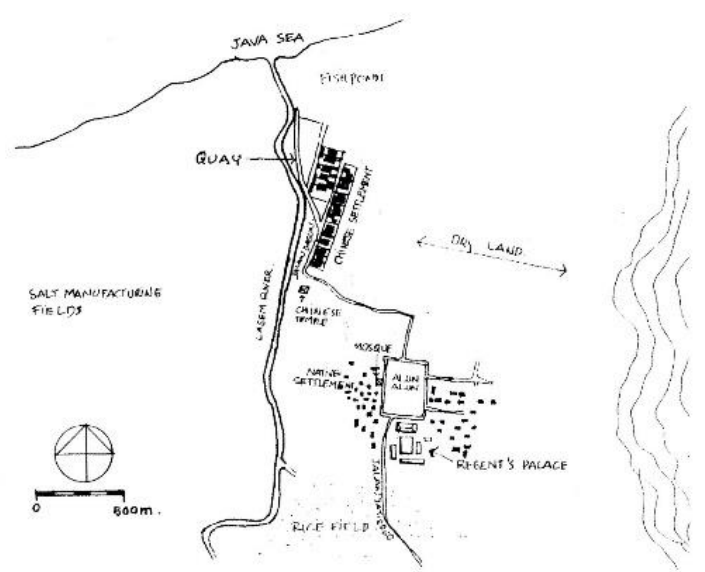

Gambar 2. Lasem Tahun 1588, setelah bupati memeluk Islam (Pratiwo, 2010)

Sejarah terbentuknya Lasem menurut Pratiwo (2010), pada akhir abad ke-15, setelah Islam masuk ke Pulau Jawa maka Kerajaan Hindu mengalami 
kemunduran. Tahun 1588, Islam diterima sebagai agama bupati Lasem. Sebuah masjid, yang sekarang menjadi masjid agung daerah Lasem, dibangun di sebelah barat alun-alun (Gambar 2). Mengikuti bupatinya, masyarakat Pribumi pun memeluk agama Islam.
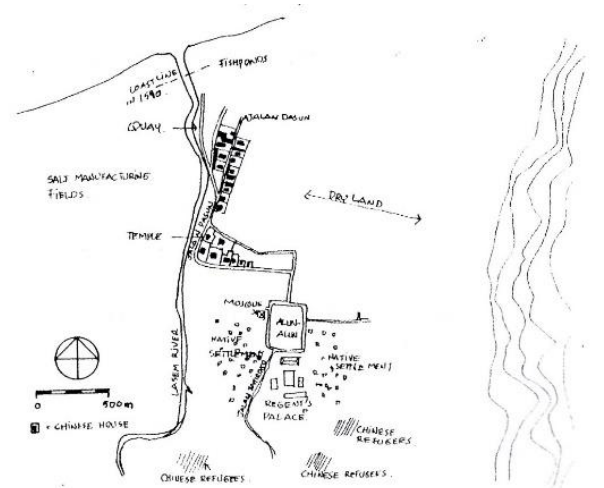

Gambar 3. Lasem Tahun 1740 para pengungsi

Tionghoa tinggal di desa-desa selatan rumah bupati.

Pada saat yang sama pecinan di Jalan Dasun

berkembang ke selatan (Pratiwo, 2010)

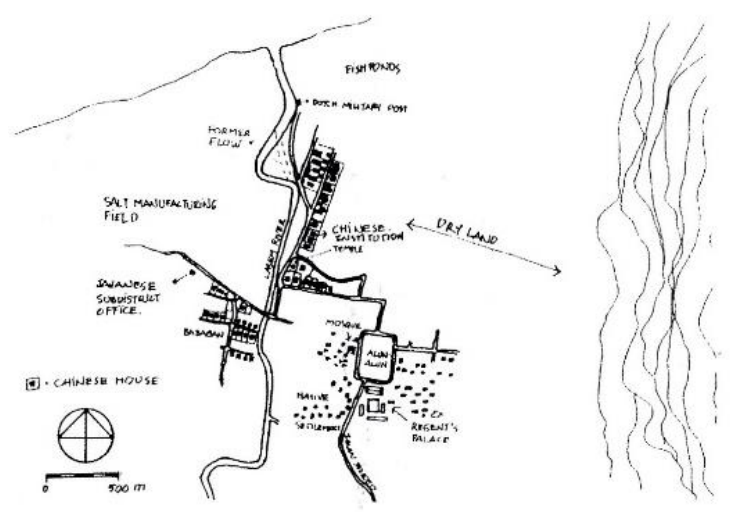

Gambar 4. Lasem tahun 1745 setelah diduduki belanda (Pratiwo, 2010)
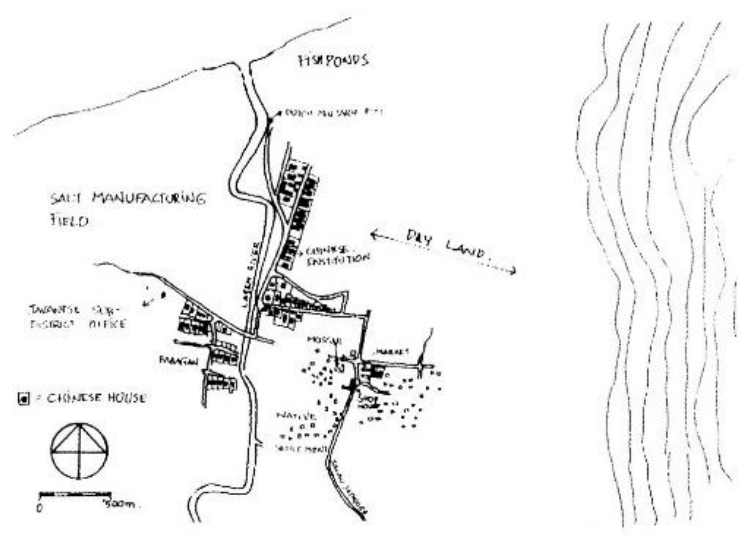

Gambar 5. Lasem Tahun 1750 alun-alun dan rumah bupati telah diganti dengan pasar dan sederet rumah toko (Pratiwo, 2010)

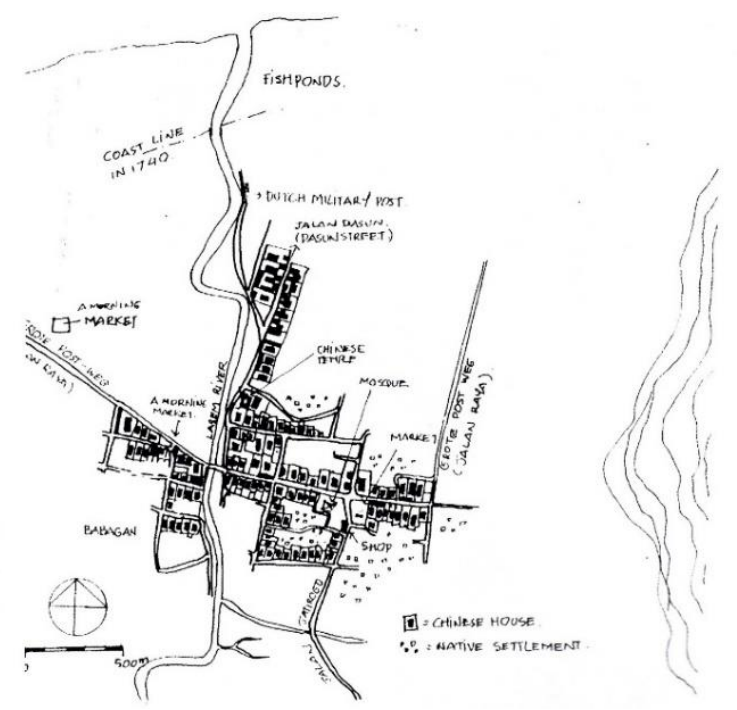

Gambar 6. Lasem Tahun 1811 pembangunan jalan Daendels (Pratiwo, 2010)

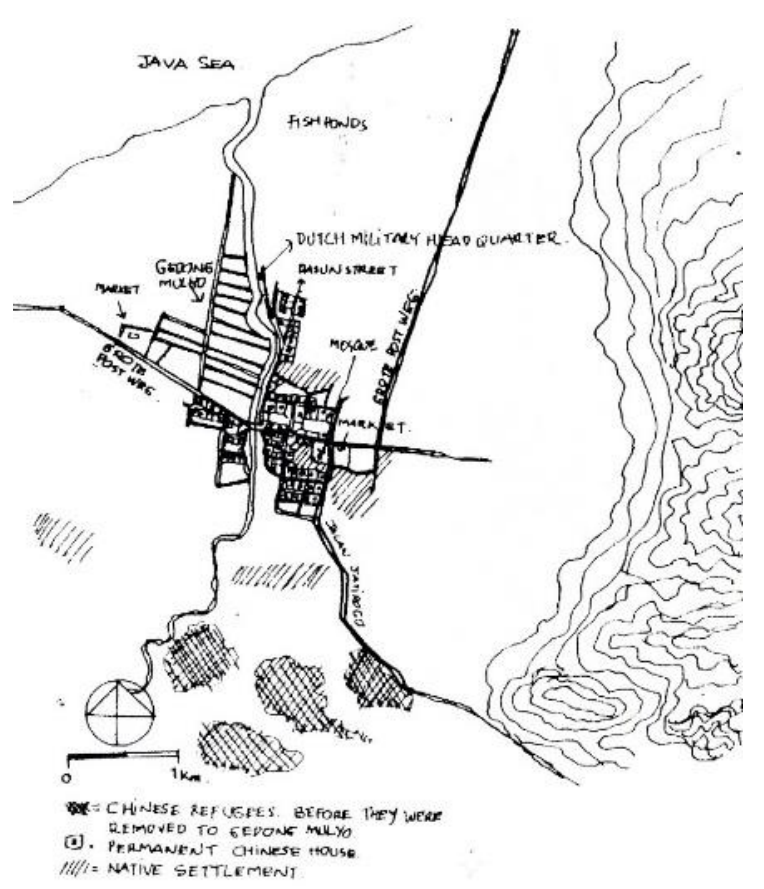

Gambar 7. Lasem Tahun 1841 Desa di sekitar Lasem sebelum Wijkenstese dan permukiman baru di Gedung Mulyo setelah Wijkenstelsel (Pratiwo, 2010)

Berdasarkan data Lasem memiliki masa perkembangan yang sangat berjenjang dari waktu ke waktu, antara lain sebagai berikut:

1. Masa Hindu (gambar 1)

Pada 1513 Kerajaan Hindu Majapahit dikalahkan oleh Kerajaan Islam Demak . Pusat Politik berpindah ke 
Demak terletak $70 \mathrm{~km}$ di sebelah barat Lasem. Tahun 1568 karena muncul kekuatan militer dibawah Arya Penangsang yang menakutkan sultan Demak, kerajaan dipindah ke Pajang. Arya Penangsang kemudian dikalahkan oleh Senopati yang membangun kerajaan Islam di kota Gede.

2. Masa Islam (gambar 2)

Tahun 1588, islam diterima sebagai agama bupati lasem. Sebuah masjid, yang sekarang menjadi masjid agung daerah lasem, dibangun di sebelah barat alunalun. Mengikuti bupatinya, masyarakat pribumi pun memeluk islam.

3. Datangnya Tionghoa (gambar 3)

Pada 1740, banyak orang Tionghoa yang melarikan diri dari Batavia dan mengungsi di Lasem. Dengan bertambahnya populasi orang Tionghoa, lasem menjadi pusat perlawanan terhadap penjajah Belanda yang kuat.

4. Belanda menguasai lasem (gambar 4)

Kantor bupati berubah menjadi kecamatan, Pada 1745 Belanda menyerang Lasem dan berhasil menguasai kotaLasem dan sekitarnya yang kemudian dijadikan satu wilayah pemerintahan kecamatan dan kabupaten dipindah ke Rembang.

5. Perubahan fungsi alun-alun (gambar 5)

Alun-alun berubah menjadi pasar, pada 1750 Belanda merubah alun- alun menjadi pasar dan menjual rumah bupati kepada orang Tionghoa yang kemudian memanfaatkan lahannya untuk membangun toko . Sejak itu seluruh daerah urban Kecamatan Lasem merupakan pecinan.

6. Terbentuknya jalan Daendels (gambar 6)

Muncul Jalan Deandels yang membelah alun-alun dan menjadikan kerangka kota Lasem yang baru.

7. Permukiman baru (gambar 7)

Gambar Desa-desa disekitar Lasem sebelum Wijkenstelsel 1841 dan permukiman baru diGedung Mulyo setelah

Lasem abad ke-20 menurut Pratiwo (2010) Pada Abad ke-20 Lasem berkembang sebagai kota modern, setelah Belanda membangun galangan kapal dan pembuatan rel kereta api untuk menghubungkan Lasem dengan kota disekitarnya, di pedalaman maupun di pantai utara Jawa (Gambar 8a). Pemerintah Hindia Belanda membangun infrastruktur untuk menjalankan fasilitas modern tersebut. Belanda membangun infrastruktur lain seperti jaringan telepon, telegrap dan listrik yang kemudian didistribusikan ke seluruh kota pecinan Lasem, sehingga roda kehidupan modern dimulai. Dari pembangunan stasiun rel kereta api dan kedatangan Jepang pada tahun 1942 tidak ada perubahan yang signifikan dan ketika Jepang menduduki Lasem pada suasana perang aktifitas perdagangan dipelabuhan berhenti. Jepang menempati rumah-rumah tua di utara jalan Dasun sebagai markas (Gambar 8b) semua etnis di Kecamatan Lasem diletakkan di bawah Pemerintahan Militer Jepang.
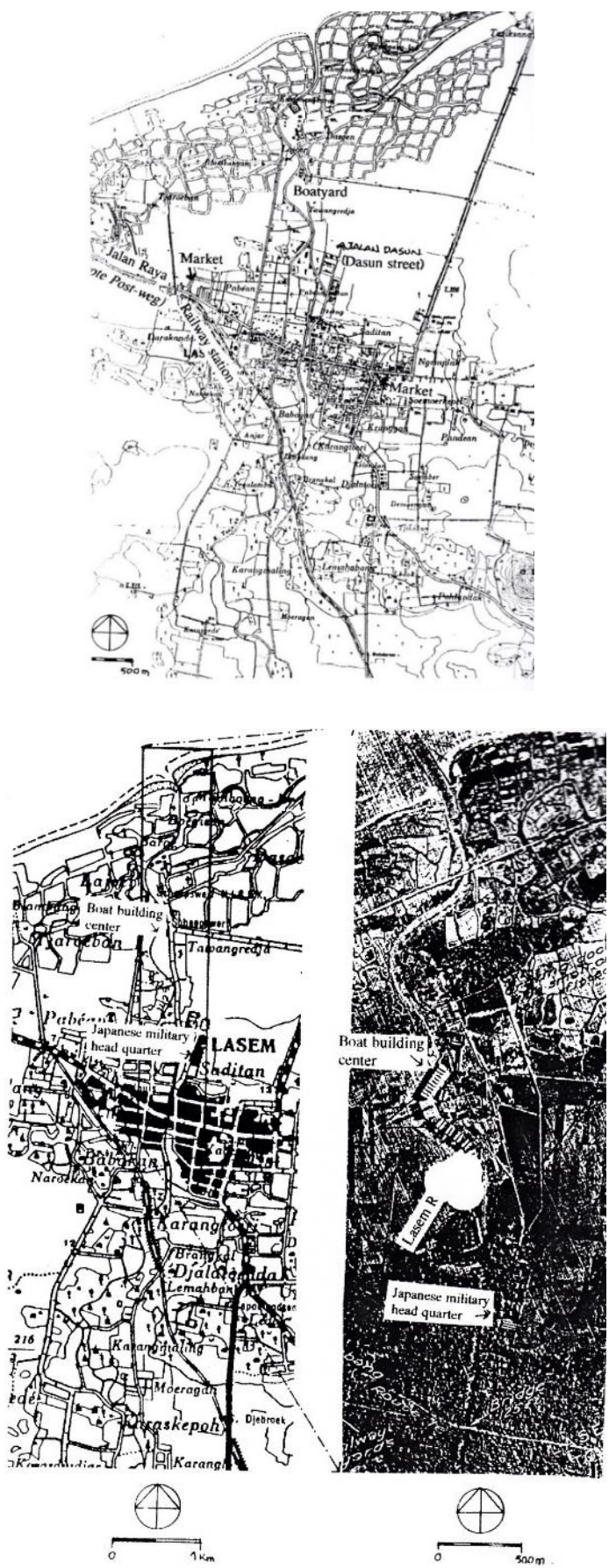

Gambar 8. (a) Awal Abad 20, Kereta Api dan

Galangan kapal sudah terbangun. (b) Pusat pembuatan kapal dan markas jepang selama perang dunia II (1942-

1945) gambar diambil dari foto udara rencana penyerangan tentara sekutu (Pratiwo, 2010) 


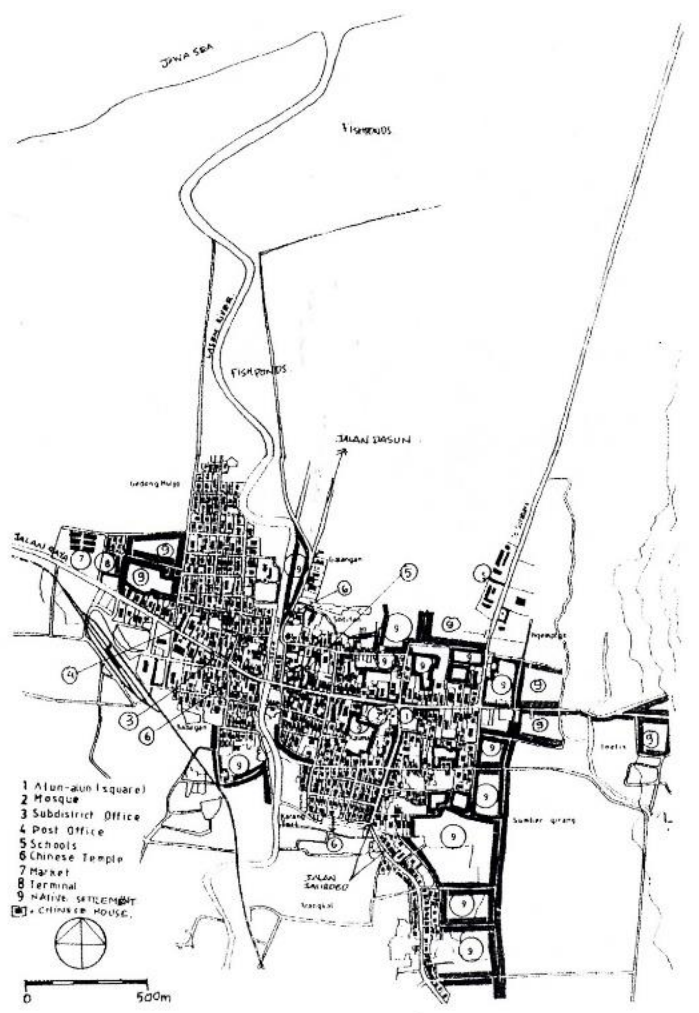

Gambar 9. Lasem 1990 an (Pratiwo, 2010)

Saat ini Lasem terletak $2 \mathrm{~km}$ dari garis pantai dan dibagi menjadi bagian timur dan barat oleh Sungai Lasem (Gambar 9). Permukiman Tionghoa atau Pecinan berada di kota dan di kelilingi oleh permukiman Jawa di pinggiran kota. Di sepanjang bagian utara Jalan Dasun, di depan rumah-rumah tua yang kosong sejumlah pemukim Jawa mendirikan rumahnya dengan tata letak tidak beraturan (Gambar 9 dan 10). Permukiman Pribumi juga muncul di sepanjang Jalan Jatirogo ke selatan, dan ke arah timur menuju bukit.
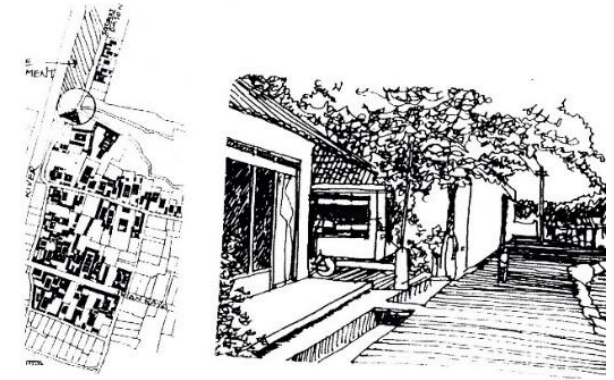

Gambar 10. Permukiman orang Jawa di Jalan Dasun (Pratiwo, 2010)

Luas Kota Lasem 1.226 Ha dengan jumlah penduduk 24.065 jiwa yang $11 \%$ nya adalah warga Tionghoa. Penduduk yang migrasi ke luar kota tiap tahunnya $0,8 \%$ dan yang berpindah ke kota ini mencapai hampir $0,4 \%$ dari jumlah penduduk keseluruhan. Luas lahan yang tertutup bangunan hanya 32,8\% dengan kepadatan penduduk 20 jiwa/ha sebab banyak rumah yang kosong atau dihuni hanya oleh sepasang orang tua. Hampir semua orang Tionghoa usia muda pindah ke dan tinggal di kota besar serta hanya sedikit yang kembali ke kota asalnya di waktu Iibur.

\section{METODE PENELITIAN}

Penelitian ini menggunakan metode deskriptif eksploratif dengan model penganalisaan deskriptif kualitatif dan pendekatan morfologi struktur ruang permukiman Tionghoa di Kota Lasem, melalui tahapan sebagai berikut: (a) pengetahuan sejarah pada kawasan penelitian; (b) observasi dan identifikasi lokasi penelitian dan pemetaan; (c) analisa morofologi kawasan persebaran permukiman; (d) kesimpulan dari analisa.

\section{HASIL PENELITIAN DAN PEMBAHASAN}

Berkembangnya permukiman yang bercirikan bangunan Tiong Hoa menurut (Pratiwo, 2010) dimulai dari datangnya etnis Tionghoa pertama kali pada tahun 1416 M ke pulau Jawa melalui Lasem untuk melakukan perdagangan. Pendaratan pertama orang Tionghoa dari perjalanan berlayar ke pulau Jawa terdapat di desa Galangan, Kota Lasem, yang kemudian mulai bermukim di tepi sungai Babagan secara linear sejajar dengan sungai. Melekatnya kepercayaan geomancy Tionghoa, rumah-rumah diorientasikan ke sungai dan dilatarbelakangi oleh perbukitan, dengan dibangun kelenteng di ujung jalan yang digunakan sebagai penjaga permukiman.

Sejak Belanda berhasil menjajah dan menguasai pantai utara Jawa setelah terjadinya pembantaian Tionghoa di Batavia, bentuk permukiman diatur dengan memisahkan antar etnis ke wilayah yang berbeda, sehingga hal ini menjadi awal persebaran permukiman etnis Tionghoa yang menyatu dengan penduduk pribumi di Lasem.

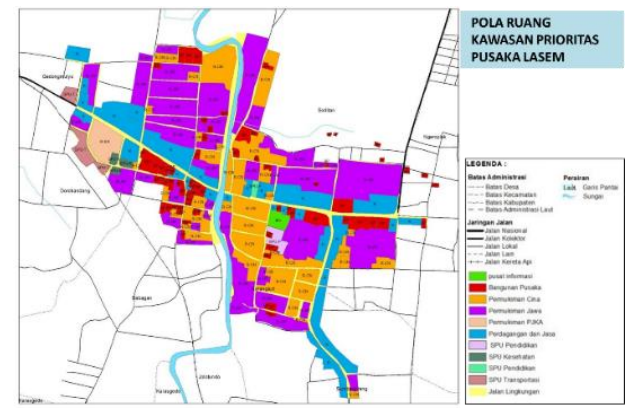

Gambar 11. Peta Pola Ruang Kawasan Prioritas Pusaka Lasem (RTBL Kawasan Pusaka Lasem Kabupaten Rembang, 2017)

\section{Batas Kawasan Penelitian}

Kawasan Penelitian dalam (RTBL (Rencana Tata Bangunan dan Lingkungan) Kawasan Pusaka Lasem 
Kabupaten Rembang, 2017) memiliki luas \pm 60 Ha dibagi menjadi 3 (tiga) segmen yang meliputi 6 desa yaitu desa Gedongmulyo, desa Soditan, desa Karangturi, desa Babagan, desa Dorokandang dan desa Sumbergiang (gambar 6).

Segmen 1: Kawasan Jl. Sumber Girang - Jl. Sunan Bonang, dimulai dari perempatan antara $\mathrm{Jl}$. Sumber Girang, Jl. Kajar dan Jl.Sunan Bonang dekat dengan pondok pesantren putri Nailunnajah sampai pada perbatasan desa Soditan dan desa Karangturi. Di dalamnya meliputi kawasan cagar budaya pusat wisata agama Masjid Jami' Lasem, alun-alun Lasem, kawasan pecinan Karangturi dan Tiongkok kecil Heritage Lasem dengan luas $\pm 25 \mathrm{Ha}$. Segmen 2: Kawasan Jl. Sunan Bonang - Sungai Babagan, dimulai dari Jl.Sunan Bonang sampai di kawasan tepian sungai Babagan pada desa Soditan, desa Karangturi, desa Gedongmulyo dan desa Babagan. Di dalamnya meliputi kawasan cagar budaya Lawang Ombo, klenteng $\mathrm{Cu}$ An Gio, pondok pesantren dll dengan luas $\pm 17,5 \mathrm{Ha}$. Segmen 3: Sungai Babagan Kawasan Jl. Sultan Agung, dimulai dari kawasan tepian sungai Babagan pada desa Soditan, desa Karangturi, desa Gedongmulyo dan desa Babagan. Sampai pada Jl.Sultan Agung dekat dengan SMP Negeri 1 Lasem. Didalamnya meliputi kawasan cagar budaya kampung batik Lasem dan kampung pecinan Gedongmulyo dengan luas $\pm 19,5$ Ha.

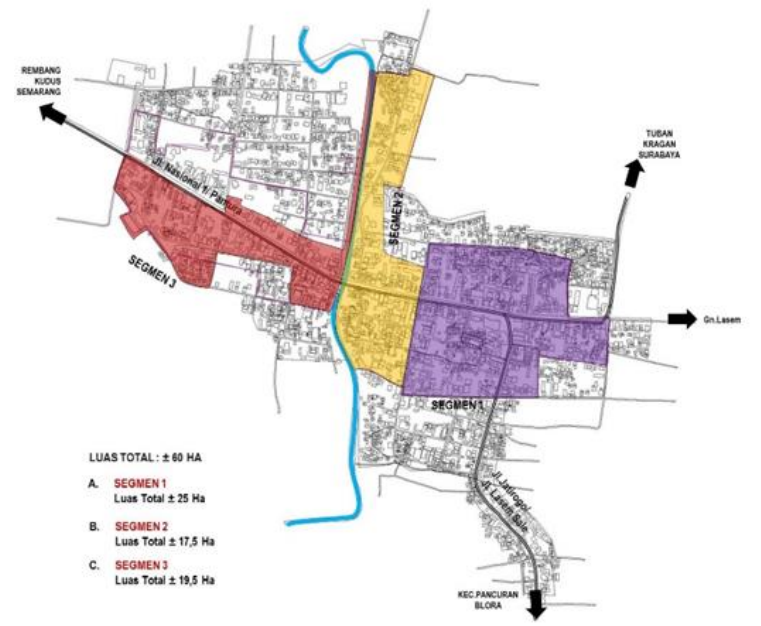

Gambar 12. Peta Pembagian Segmen (RTBL Kawasan Pusaka Lasem Kabupaten Rembang, 2017)

\section{Tata Guna Lahan (gambar 20)}

Secara umum pada kawasan penelitian berkembang fungsi permukiman dengan tingkat kepadatan yang bervariasi mulai dari kepadatan tinggi hingga sedang. Selain itu, pada kawasan inti juga telah berkembang berbagai fungsi pelayanan baik dalam skala regional maupun lokal. Selanjutnya apabila dilihat dari sebaran penggunaan lahan menurut desa di Kecamatan Lasem terlihat ada beberapa jenis penggunaan lahan yang relatif menyebar hampir di semua wilayah desa, namun sebagian jenis penggunaan lahan yang lain hanya terdapat di beberapa desa saja.

Jenis penggunaan lahan yang relatif menyebar antara lain adalah kebun campuran, jalan, persawahan, tegalan, dan permukiman. Khusus untuk permukiman, permukiman kepadatan sedang hingga sangat rendah polanya relatif menyebar, sedangkan untuk permukiman kepadatan tinggi dan sangat tinggi hanya terdapat pada beberapa wilayah desa saja, seperti di Karangturi, Dorokandang. Sebaran yang relatif tidak merata dijumpai untuk jenis penggunaan lahan berupa fasilitas pelayanan. Sebaran fasilitas umumnya tidak terdapat di semua desa, namun untuk fasilitas pendidikan sebarannya relatif lebih merata dibandingkan fasilitas lainnya. Penggunaan lahan secara umum di kawasan penelitian untuk kegiatan permukiman. Perkembangan yang cukup cepat pada umumnya di jalan utama karena untuk kegiatan ekonomi (perdagangan dan jasa).

Permasalahan pemanfaatan lahan yang perlu diperhatikan di kawasan adalah masalah perubahan fungsi hunian untuk perdagangan dan jasa yang berakibat pada bentuk bangunan dan permasalahan bangunan kuno yang kurang terpelihara dan tidak difungsikan sehingga berpengaruh pada permasalahan kerusakan lingkungan.

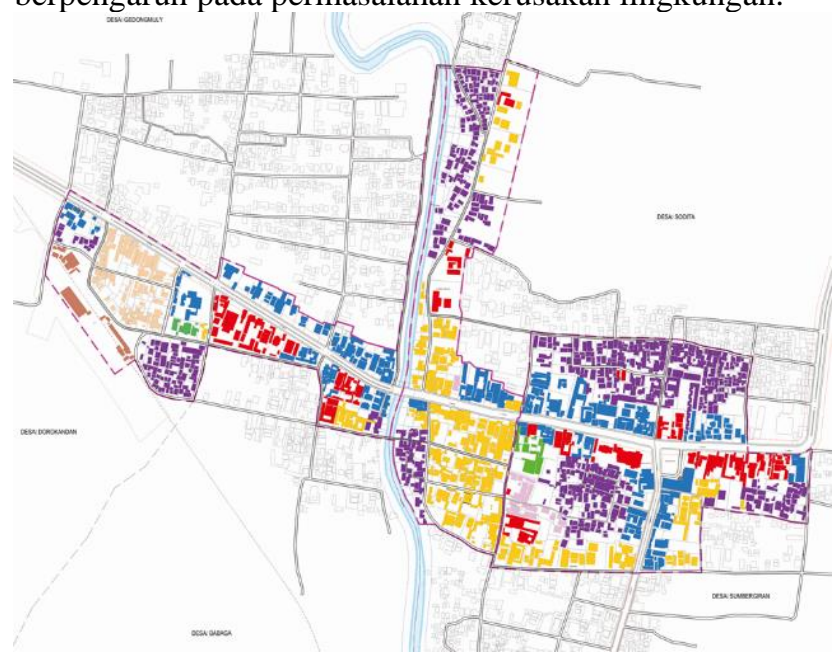

Gambar 13. Tata Guna Lahan (RTBL Kawasan Pusaka Lasem Kabupaten Rembang, 2017)

Tabel 1. Tata guna lahan

\begin{tabular}{clrr}
\hline \multirow{2}{*}{ No } & \multirow{2}{*}{ Peruntukan Lahan } & \multicolumn{2}{c}{ Luas } \\
\cline { 3 - 4 } & & $\mathbf{m} 2$ & $\mathbf{\%}$ \\
\hline 1 & Pusat Informasi & 7.071 & $1 \%$ \\
\hline 2 & Bangunan Pusaka & 61.422 & $11 \%$ \\
\hline $\mathbf{3}$ & Permukiman Cina & $\mathbf{1 3 3 . 3 8 5}$ & $\mathbf{2 5 \%}$ \\
\hline 4 & Permukiman Jawa & 158.566 & $29 \%$ \\
\hline 5 & Permukiman PJKA & 23.187 & $4 \%$ \\
\hline
\end{tabular}




\begin{tabular}{|c|c|c|c|}
\hline \multirow{2}{*}{ No } & \multirow{2}{*}{ Peruntukan Lahan } & \multicolumn{2}{|c|}{ Luas } \\
\hline & & $\mathbf{m} 2$ & $\%$ \\
\hline 6 & Perdagangan \& Jasa & 124.854 & $23 \%$ \\
\hline 7 & SPU Pendidikan & 8.948 & $2 \%$ \\
\hline 8 & SPU Kesehatan & 7.827 & $1 \%$ \\
\hline 9 & SPU Transportasi & 13.808 & $3 \%$ \\
\hline & LUAS TOTAL & 539.068 & $100 \%$ \\
\hline
\end{tabular}

\section{Perkembangan Kegiatan Ekonomi dan Sosial}

Munculnya 3 (tiga) lokasi pasar pagi oleh pedagang etnis Tionghoa pada masa pembangunan jalan arteri tahun 1811 menurut (Pratiwo, 2010) merupakan cikal bakal adanya pusat perekonomian di sepanjang jalan arteri.

Setelah masa pergolakan di Indonesia termasuk di Kota Lasem selesai, pasar pagi yang terdapat di ujung barat kota lasem berubah menjadi pasar utama dengan dibangun terminal di dekatnya, sedangkan pasar pagi yang terdapat di pertigaan jalan babagan menjadi awal dari munculnya toko-toko baru di sepanjang jalan raya, serta pasar pagi yang berada di sebelah selatan tepatnya di jalan Jatirogo menjadi pusat kegiatan ekonomi karena berlokasi di tepi jalan di depan sederetan toko-toko. Sebagian besar para pedagang pada waktu itu adalah para penduduk etnis Tionghoa sehingga bangunan ruko memiliki ciri khas arsitektur Tionghoa.

Terbentuknya pusat perekonomian di sepanjang jalan arteri menjadikan pola permukiman di sekitar arteri menjadi abstrak. Banyak diantara para pribumi menempati bangunan bergaya arsitektur Tionghoa karena banyak dari mereka (para pedagang etnis Tionghoa) lebih memilih berjualan di kota-kota besar, dan ada pula karena hasil perkawinan antara orang etnis Tionghoa dan pribumi.

Pembauran permukiman cina dan pribumi yang berangsur sekian tahun memunculkan akulturasi budaya dan toleransi yang sangat kuat di Kota Lasem, banyak dari orang pribumi yang mengikuti kerja keras dan keuletan dalam berdagang dari para orang Tionghoa, sebaliknya begitupula orang Tionghoa tidak sedikit yang menganut ajaran agama islam terlihat beberapa lokasi pondok yang tersebar di kecamatan Lasem dan mengikuti beberapa budaya jawa setempat.

\section{Perubahan Struktur Kawasan}

Morfologi kota Lasem menurut (Pratiwo, 2010) terbentuk berawal dari:

1. Alun-alun, sebagai pusat awal terbentuknya Lasem karena pada masa tersebut Lasem adalah kerajaan dibawah kekuasaan Majapahit.
2. Sungai, jalur transportasi yang pada awalnya orang Tionghoa masuk ke Lasem dan membentuk permukiman maupun tempat ekonomi yang strategis.

3. Jalan Daendels, Belanda sengaja menghilangkan atau membelah alun-alun Lasem dengan membuat jalan Daendels sebagai kerangka baru (struktur kawasan) untuk tidak menjadikan pusat kota yang lebih dominan pada masa kerajaan Lasem. Sehingga tumbuhkan area-area ekonomi disepanjang jalan dan alun-alun yang dirubah menjadi pusat ekonomi.

4. Rel Kereta Api, Belanda mendirikan dan membangun rel kereta api untuk dapat mendistribusikan logistik yang berasal dari masyarakat pribumi dan Tionghoa.

\section{Perubahan Perkembangan Kawasan}

Perubahan struktur kawasan dan land use kota Lasem menurut (Pratiwo, 2010) bukan serta merta oleh masyarakat Tionghoa yang sampai saat ini bangunan mereka masih dibilang utuh tetapi berdasar sejarah tertulis dan informasi dari tokoh-tokoh setempat sudah tergambarkan pada peta-peta diatas. Sehingga dapat dikategorikan perkembangan kawasan berdasarkan paksaan oleh penjajah Belanda dan masyarakat pribumi yang tersisihkan. Akan tetapi sampai dengan saat ini masyarakat Tionghoa masih berpegang teguh terhadap tatanan sistem permukiman atau aturan penataan rumah sesuai dengan filosofi leluhur mereka, sedangkan terbentuknya ruang-ruang ekonomi mengikuti struktur jalan utama kota sebagai area perdagangan dan jasa

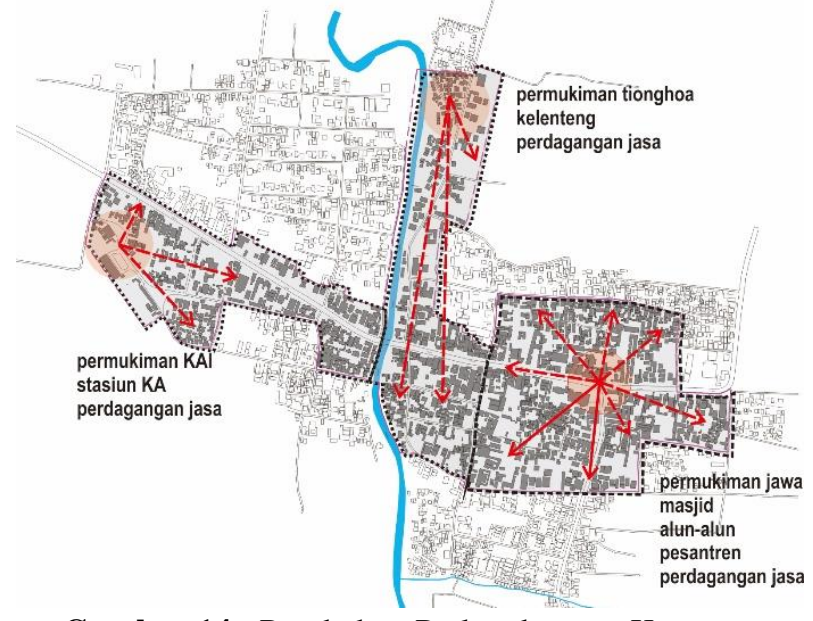

Gambar 14. Perubahan Perkembangan Kawasan (RTBL Kawasan Pusaka Lasem Kabupaten Rembang, 2017)

1. Perubahan Kawasan Tumbuh Kembang Cepat. Berdasarkan sejarah Lasem mulai periode Lasem dibawah Kekuasaan Kerajaan, Lasem dibawah Kekuasaan Kerajaan Islam, Lasem masa Kolonial dan Lasem pada Masa Kemerdekaan, perkembangan Lasem semakin berkembang dan tumbuh dengan cepat. Pertumbuhan dan perkembangan kawasan 
ditandai dengan semakin meningkatnya aktivitas permukiman, kegiatan perdagangan, tatanan sosial maupun budaya, dan juga ekonomi masyarakat lokal. Kawasan tumbuh cepat di tiga titik ini saling memiliki konektivitas untuk mendukung masing-masing aktivitas.

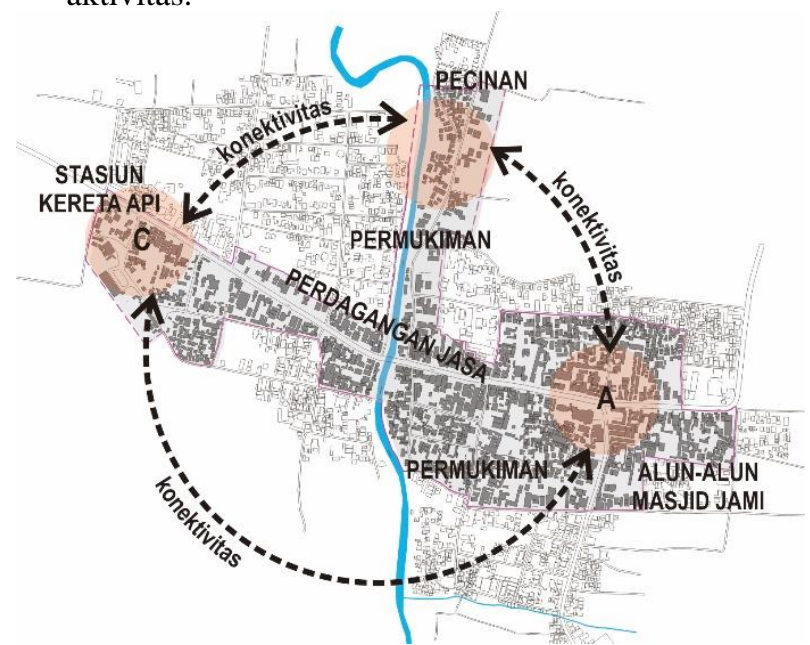

Gambar 15. Perubahan Kawasan Tumbuh Kembang Cepat (RTBL Kawasan Pusaka Lasem Kabupaten Rembang, 2017)

2. Penyebaran Perkembangan Kawasan Permukiman

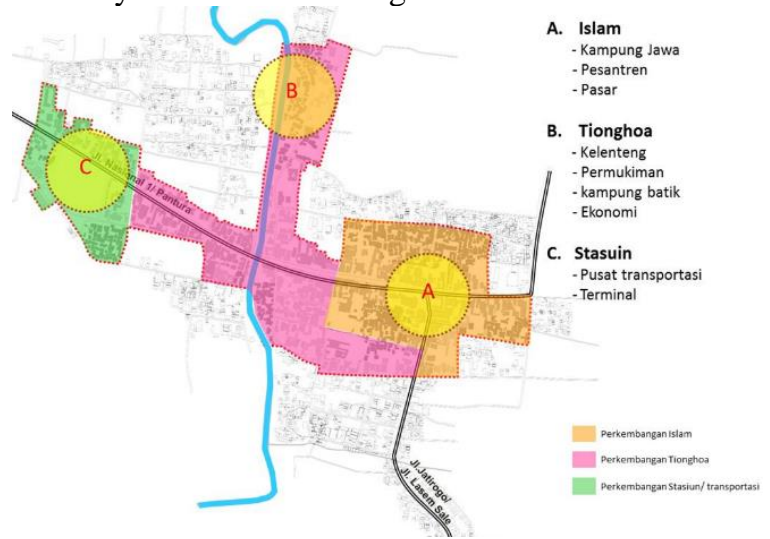

Gambar 16. Perubahan perkembangan kawasan (RTBL Kawasan Pusaka Lasem Kabupaten Rembang, 2017)

Tiga titik sebaran utama dalam perkembangan wilayah di Kota Lasem sangat terpengaruhi oleh awal mula dari sejarah titik awal permukiman maupun pusat pemerintahan (gambar 9). (a) pusat pemerintahan yang terlihat bangunan permukiman jawa, pasar, dan pesantren, (b) awal mula mendaratnya orang Tionghoa yang menyebarkan permukimannya sampai ke sebelah barat sungai dan sisi selatan jalan daendels, (c) awal mula belanda masuk dikawasan sebelah barat Kota Lasem dan menjadi pusat transportasi sampai saat ini.

\section{Aktifitas}

Aktifitas pendukung dalam hal ini untuk membantu dan memperkuat ruang publik kota, sehingga dapat memperkuat dan saling melengkapi fisik dan aktifitas ruang satu dengan yang lainnya. Kondisi juga permasalahan aktivitas kawasan dapat dilihat pada gambar dibawah.

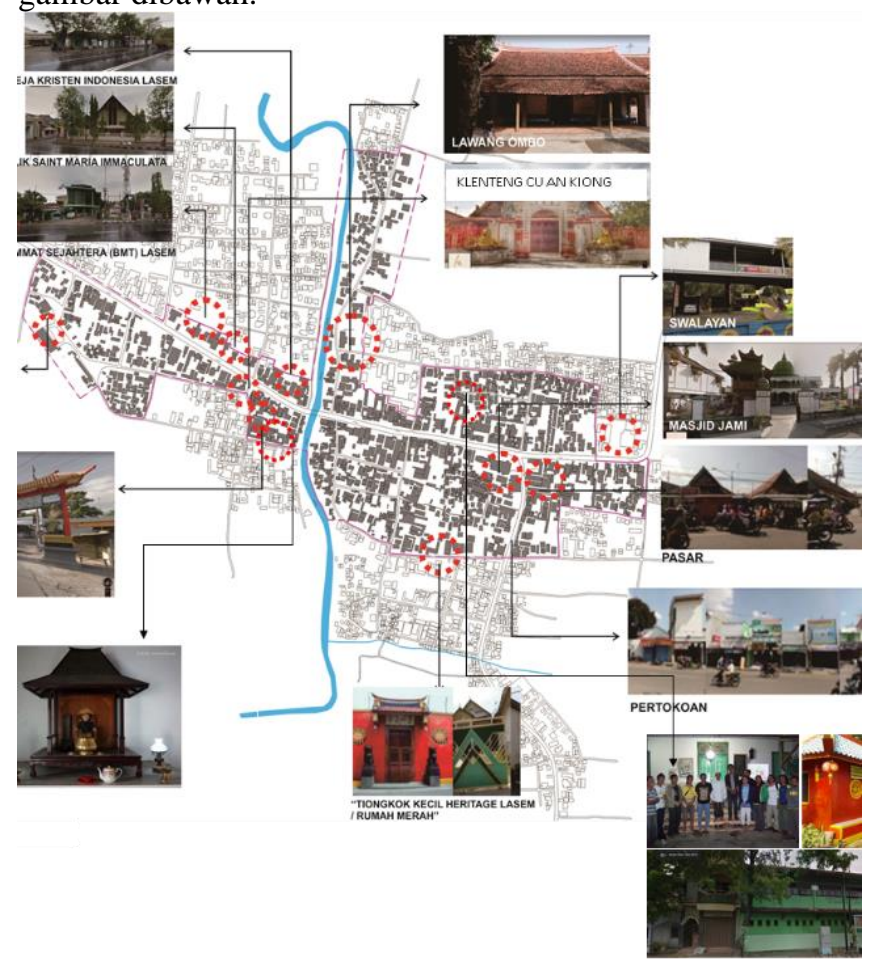

Gambar 17. Aktifitas lasem (RTBL Kawasan Pusaka Lasem Kabupaten Rembang, 2017)

\section{Transformasi Struktur Permukiman}

Struktur permukiman menurut (Pratiwo, 2010) pada waktu itu terdapat dua morfologi permukiman di Lasem. Jalan jatirogo sebagai penghubung antara rumah bupati dan alun-alun dengan permukiman penduduk asli. Sedangkan sungai dan dermaganya yang dijadikan orang Tionghoa mendirikan permukimannya di sepanjang dermaga ini (Gambar 1 dan 2).

Di tempat tersebut memiliki dua jalan sejajar yang menyatu di sebelah selatan, jalan ini menuju ke arah selatan menyusuri sungai dinamakan Jalan Dasun dan kemudian membelok ke timur menghubungkan dengan alun-alun (Gambar 1 dan 2). Lasem bukitnya terletak 2 $\mathrm{km}$ di sebelah timur dan di antaranya lahan kosong. Sehingga dari pecinan orang dapat melihat Iangsung ke kaki bukit dan pesisir dari bawahnya.

Di sepanjang dua jalan sejajar ini orang Tionghoa mengorientasikan rumah-rumahnya ke sungai. Dalam hubungannya dengan kosmologi, hal tersebut dapat diterjemahkan jika sungai didepan rumah disimbolkan sebagai burung merak berwarna merah; 
bukit yang berada di sebelah timur sebagai kura-kura hitam; laut di sebelah utara adalah macan pufih; Kelenteng Thian Siang Sing Bo, di sebelah selatan, adalah naga biru (Gambar 11).

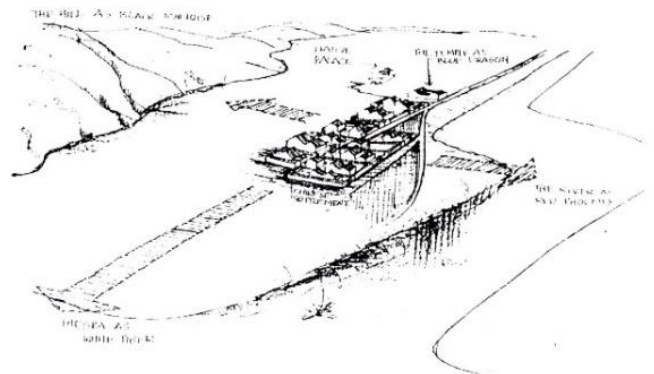

Gambar 18. Interpretasi kosmologis pecinan tertua di Kota Lasem (Pratiwo, 2010)

Kini struktur permukimannya di tentukan oleh Jalan Raya sebagai jalan arteri yang dibangun di awal abad ke-19 (Gambar 12). Jalan Raya ini menggantikan fungsi sungai sebagai alur transportasi, dan jalan ini menghubungkan bagian timur dan barat kota yang terpisah sebelumnya. Bersama dengan Jalan Jatirogo, Jalan Raya menentukan pola permukiman. Titik temu kedua jalan, yang tadinya alun-alun yang diubah menjadi pasar dan kemudian dikembalikan ke alun-alun lagi setelah merdeka.
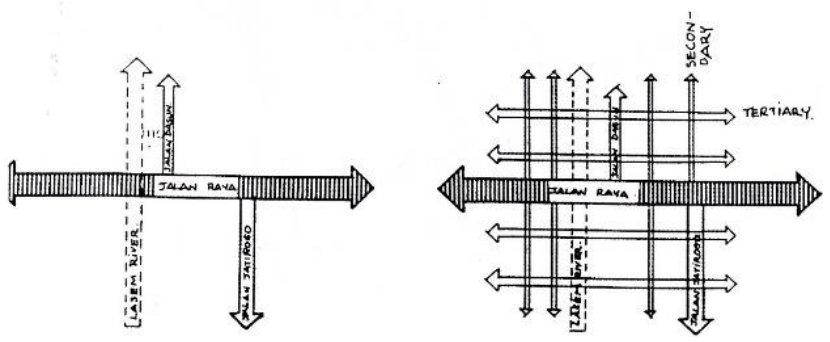

Gambar 19. Struktur dasar permukiman (Pratiwo, 2010)

Dalam konteks pola permukiman yang ada sekarang, Jalan Raya merupakan jalan primer; Jalan Jatirogo dan jalan Iain kearah utara dan selatan merupakan jalan sekunder yang menghubungkan jalanjalan tersier di dalam permukiman yang terletak pada arah timur-barat (Gambar 13). Orientasi rumah menghadap ke salah satu arah selatan atau utara mengikuti pola jalan (Gambar 14). Tidak ada rumah yang menghadap ke timur sebab arah fimur dipercayai sebagai tempat kura-kura hitam. Orientasi dua sisi antara sungai dan bukit, seperti ditemukan pada pecinan mula-mula di kota ini, tidak ditemukan pada bagian kota yang belakangan dibangun.

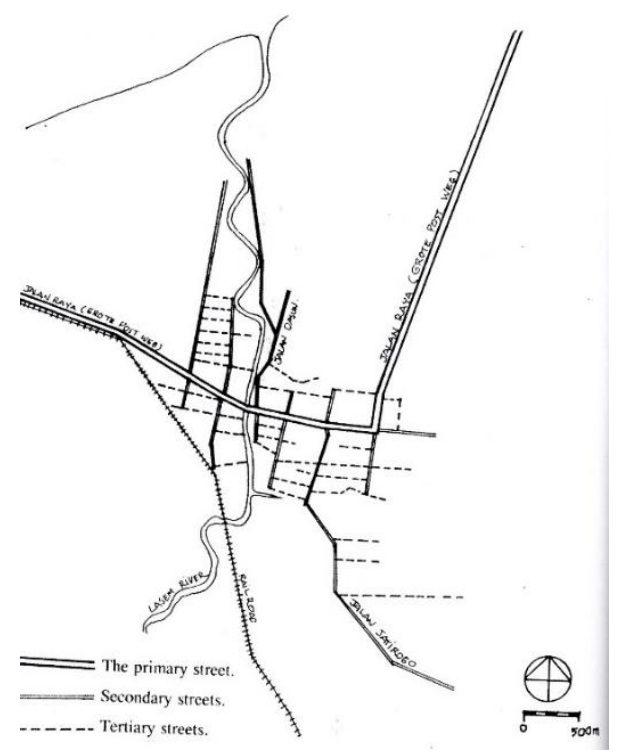

Gambar 20. Hirarki jalan (Pratiwo, 2010)

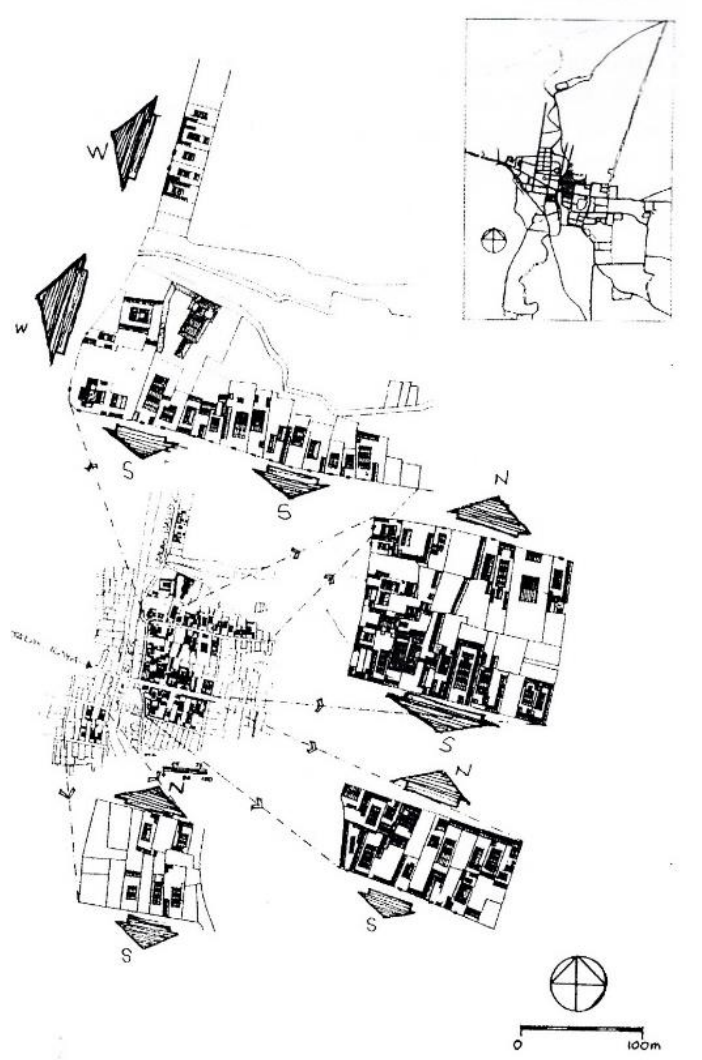

Gambar 21. Orientasi rumah ke utara, selatan dan barat. Tidak ada rumah yang berorientasi ke timur (Pratiwo, 2010)

\section{Transformasi Kehidupan di Jalan}

Sebelum pelebaran jalan pada 1970-an dan 1991, Iebar Jalan Raya adalah 10 meter dengan badan jalan selebar 6 meter (Gambar 15 dan 16). Dua deret 
pohon asam dan kanopi rumah yang lebar menciptakan tepi jalan yang teduh di mana penduduk kota dapat bercengkerama. Kereta kuda yang menjadi alat transportasi utama tidak mengganggu suasana intim ruang jalan.
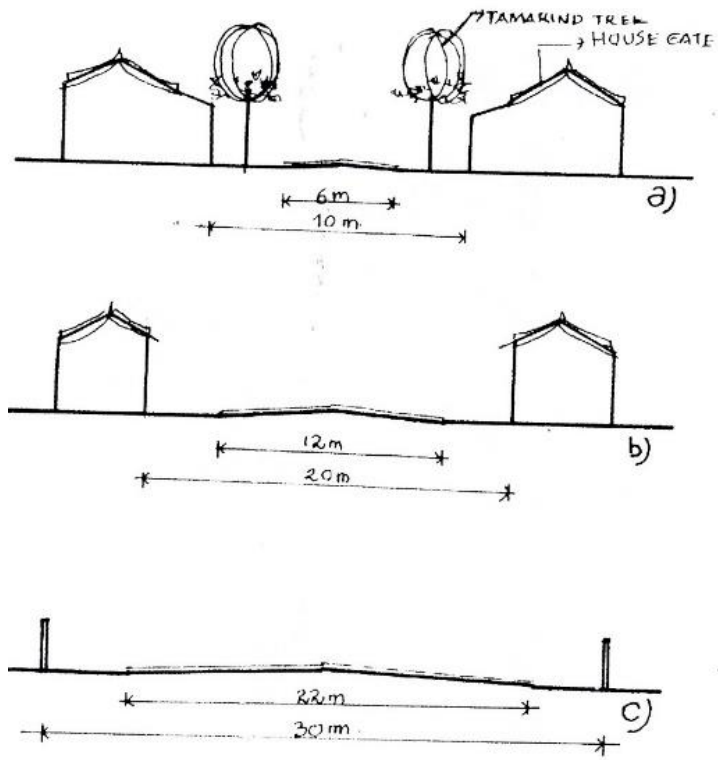

Gambar 22. Transformasi Jalan Raya (a. Sebelum pelebaran jalan 1970 an, b. Setelah pelebaran jalan 1970 an, c. Setelah pelebaran jalan 1991 (Pratiwo, 2010)

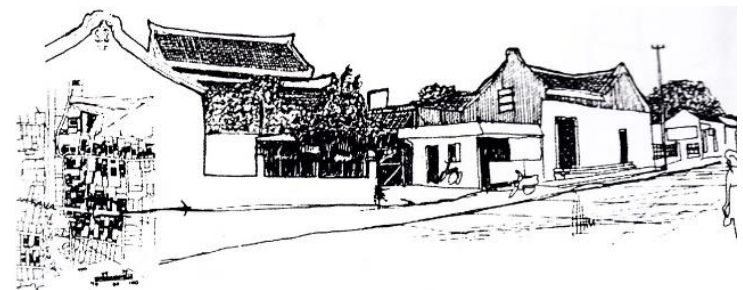

Gambar 23. Jalan Raya pasca pelebaran jalan 1970an (Pratiwo, 2010)

Berbeda dengan Jalan Raya yang lebar dan diapit oleh bangunan-bangunan yang saling berhadapan, jalan sekunder dan tersier cukup sempit,hanya 2,5 meter dan diapit oleh dinding pagar rumah yang tinggi (Gambar 17 dan 18). Jalan-jalan tidak berpohon dan panas, meninggalkan impresi membosankan; kelihatan aneh untuk iklim tropis, dan seolah-olah hanya untuk tewat saja bukan untuk tempat berkumpul. Berlawanan dengan itu, di balik dinding pagar, terlihat dari jalan, adalah pohon-pohon rindang di halaman rumah.

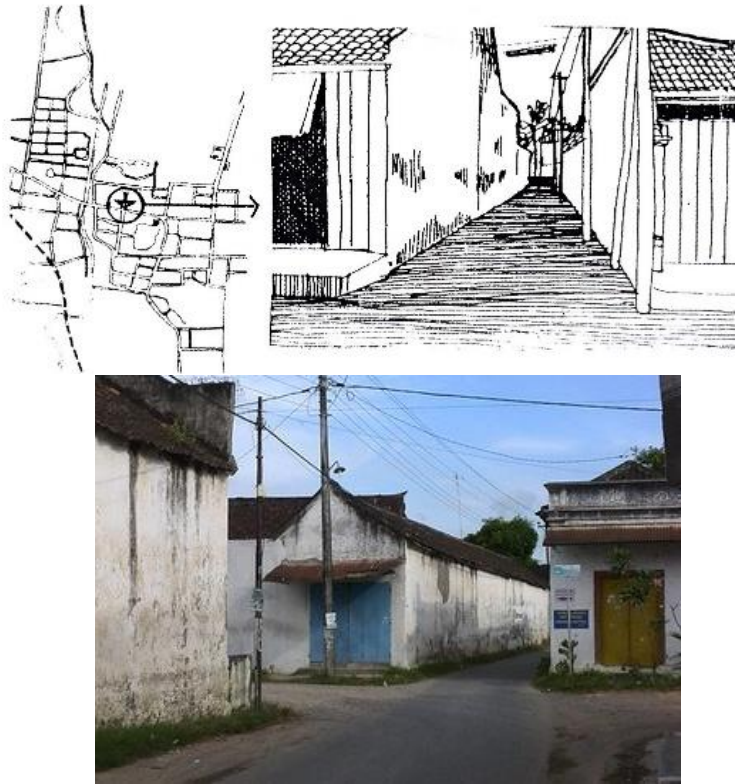

Gambar 24. Jalan sekunder (Pratiwo, 2010)
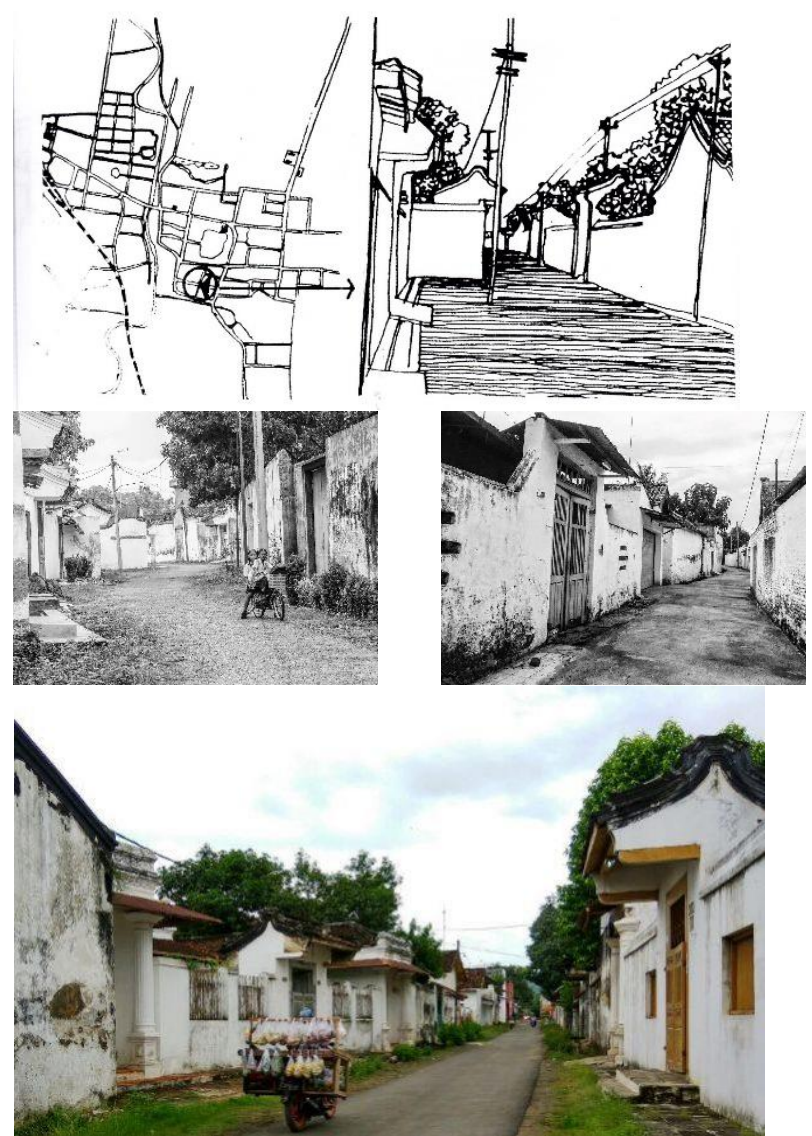

Gambar 25. Jalan tersier (Pratiwo, 2010)

Transformasi kehidupan di jalan terjadi pada jalan raya mengikuti pelebaran jalan yang menjadi 20 meter pada 1970 dan 30 meter tahun 1991. Pelbaran jalan 
menghilangkan pohon-pohon dan kanopi rumah yang Iebar (Gambar 16 dan 17). Bis dan truk begar sekarang yang melewatinya dengan kecepatan tinggi teiah menghilangkan suasana intim sebagai tempat berkumpul.

\section{Transformasi Bangunan}

Selama berabad-abad warga Tionghoa di Lasem tinggal di rumah tradisioal yang merupakan wujud arsitektur tradisionalnya karena tidak diizinkan membangun rumah bergaya Eropa. Kemudian pada awal abad ke-20 Lasem berkembang menjadi kota modern, orang Tionghoa mendapat kebebasan untuk membangun rumah dengan gaya apapun sampai akhirnya orang Tionghoa menjadi peran penting dalam pengembangan arsitektur modern di perkotaan. Perkembangan ini akhirnya membawa arsitektur tradisional Tionghoa menjadi tidak terpisahkan di wilayah Lasem.

Rumah tradisional Tionghoa bukan hanya berfungsi sebagai tempat kegiatan sosial dan ekonomi tetapi juga sebagai tempat ritual para dewa dan arwah leluhur yang memiliki tempat khusus untuk sembahyang yaitu di pusat organisasi ruang rumah (altar leluhur). Dalam transformasi gaya arsitektur modern, tata ruang tradisional tetap dipertahankan khususnya altar leluhur karena mereka percaya bahwa ada aturan-aturan yang harus diikuti oleh keturunan Tionghoa.

Berikut beberapa transformasi bagian bangunan menurut (Pratiwo, 2010) yang terdapat di Kota Lasem:

1. Atap

Bentuk atap arsitektur Tionghoa bermacam-macam, yang paling sering dijumpai di Indonesia diantaranya jenis atap pelana dengan ujung melengkung ke atas atau biasa disebut model Ngang Shan.
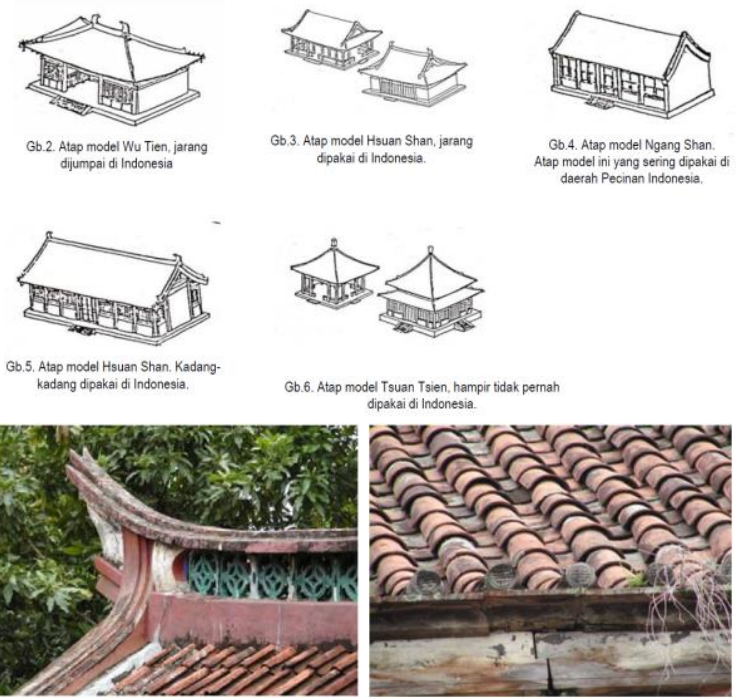

Gb.6. Atap model Tsuan Tsien, hampir tidak pernah

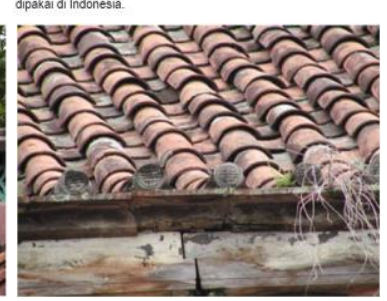

Gambar 26. Bentuk atap arsitektur Tionghoa (Pratiwo, 2010)
Arsitektur belanda mempengaruhi perubahan arsitektur atap Tionghoa dari bentuk atap pelana menjadi berbentuk atap limasan.

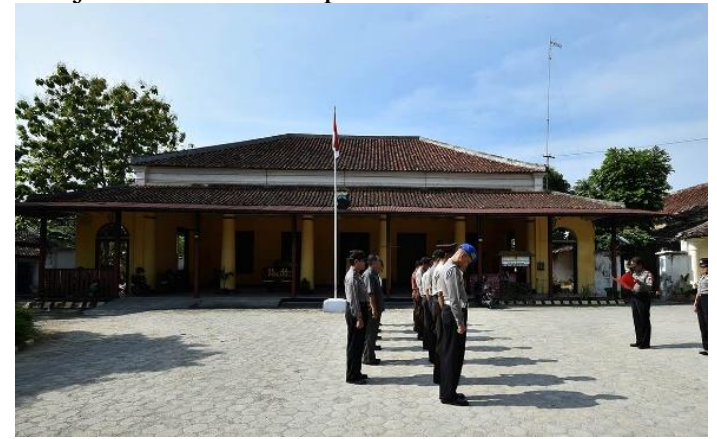

Gambar 27. Perubahan arsitektur atap Tionghoa-

Belanda rumah Liem Hong Hoen abad-19 yang sekarang menjadi polsek lasem

2. Pintu Gerbang

Bentuk pintu gerbang arsitektur Tionghoa dibuat menyerupai kelenteng untuk melindungi tanah miliknya dari orang lain. Terdapat 2 macam pintu gerbang, tipe gerbang kecil hanya digunakan untuk jalan lewat dan tipe rumah gerbang memiliki tiga ruangan dengan jalan masuk terdapat di tengah yang diapit oleh dua kamar penjaga.
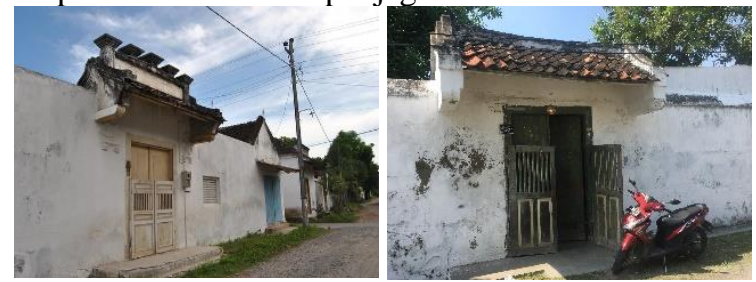

Gambar 28. Bentuk pintu gerbang rumah arsitektur Tionghoa (Foto Pribadi, 2017)

Di beberapa tempat menurut (Ayuningrum, 2019) terdapat beberapa bangunan yang mengalami transformasi karena proses asimilasi dan akulturasi budaya yang saling memengaruhi, sehingga rumah orang Tionghoa yang tersebar-sebar di Lasem tidak lagi murni berarsitektur Tionghoa.

Pengaruh arsitektur belanda terhadap perubahan arsitektur Tionghoa selanjutnya dengan adanya beberapa orang Tionghoa mengubah pagar solid/tertutup rumah mereka dengan pagar transparan.

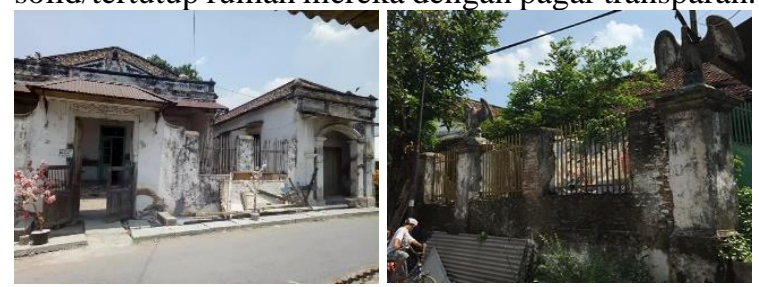

Gambar 29. Perubahan arsitektur gerbang rumah dari tertutup menjadi transparan 
3. Bentuk rumah

Rumah utama Tionghoa terletak di tengah-tengah yang dikelilingi oleh rumah samping dan belakang, diantara bangunannya terdapat halaman depan dan belakang dengan dikelilingi tembok.

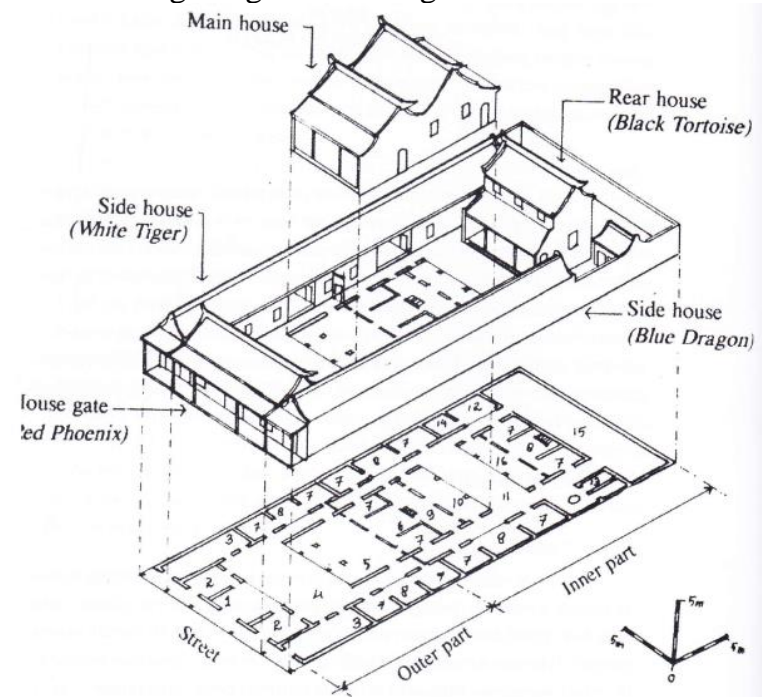

Gambar 30. Model rumah Tionghoa (Pratiwo, 2010)

Perkembangan kota modern menjadikan beberapa rumah di Lasem mengalami perubahan arsitektur. Beberapa ornamen dan fasade bangunan berubah bergaya roman.
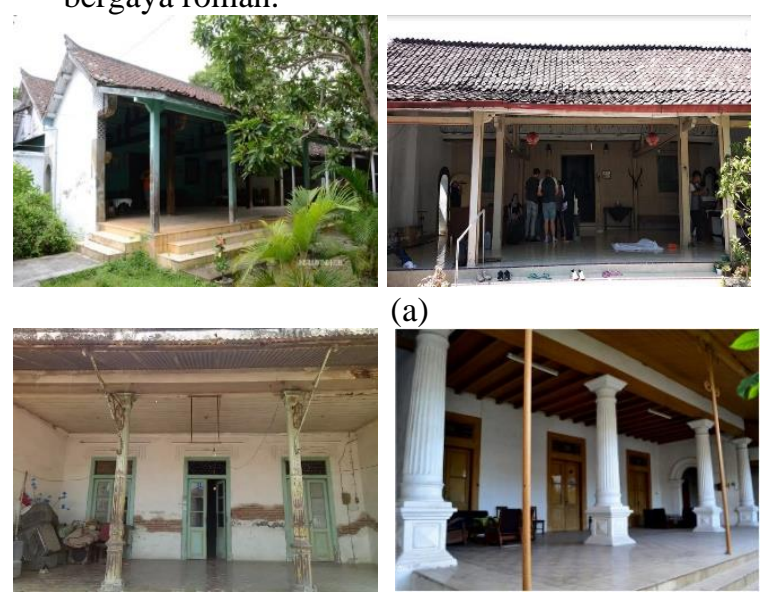

(b)

Gambar 31. (a) Bentuk rumah tradisional arsitektur Tinghoa; (b) Bentuk rumah modern arsitektur TinghoaBelanda

\section{Rumah toko (ruko)}

Setelah permukiman dibentuk oleh Belanda, para etnis Tiongkok di Lasem kemudian mulai berdagang dan bermukim di sekitar pasar dengan rumah tokonya (ruko).

Berubahnya rumah menjadi rumah toko (ruko) terjadi setelah adanya pelebaran jalan. Beberapa rumah gerbang digunakan dan/atau diganti menjadi toko dan merubah fasade tradisional ke modern dengan mempertahankan rumah utama, serta terdapat beberapa rumah yang membuka toko dengan memanfaatkan halaman depan di balik pintu gerbang rumah dan/atau gerbang kecil yang dipertahankan sebagai pagar rumah.
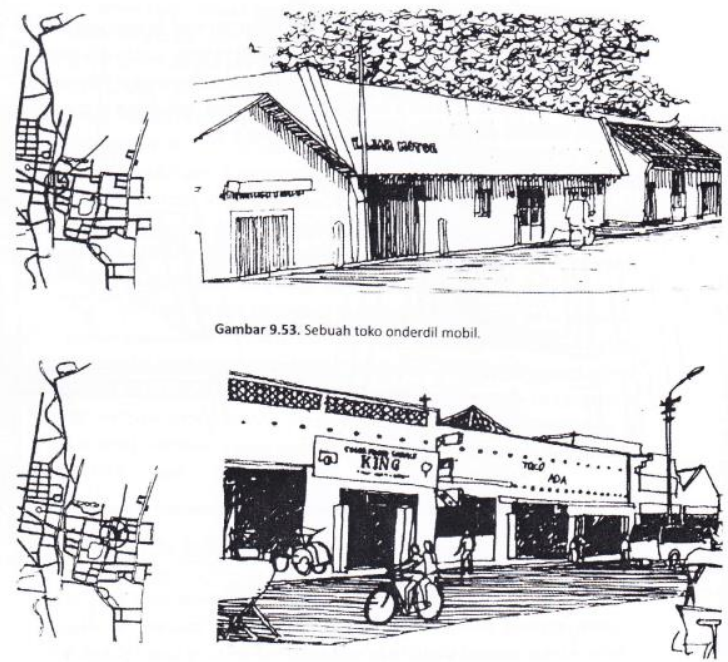

Gambar 32. Rumah gerbang yang dijadikan sebagai toko (Pratiwo, 2010)
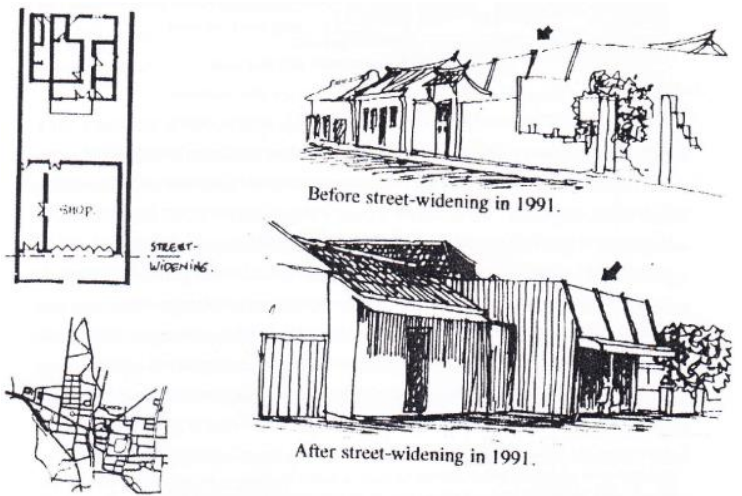

Gambar 33. Perubahan rumah toko sebelum dan setelah pelebaran jalan (Pratiwo, 2010)

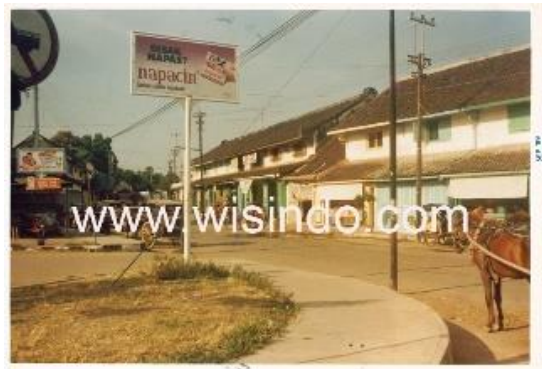

Gambar 34. Rumah toko (ruko) di Lasem tahun 1989 Jalan yang telah dibangun oleh Belanda dijadikan sebagai ruang aktivitas ekonomi bagi para etnis Tionghoa 
sehingga banyak terjadi perubahan fungsi dari perumahan menjadi daerah bisnis.

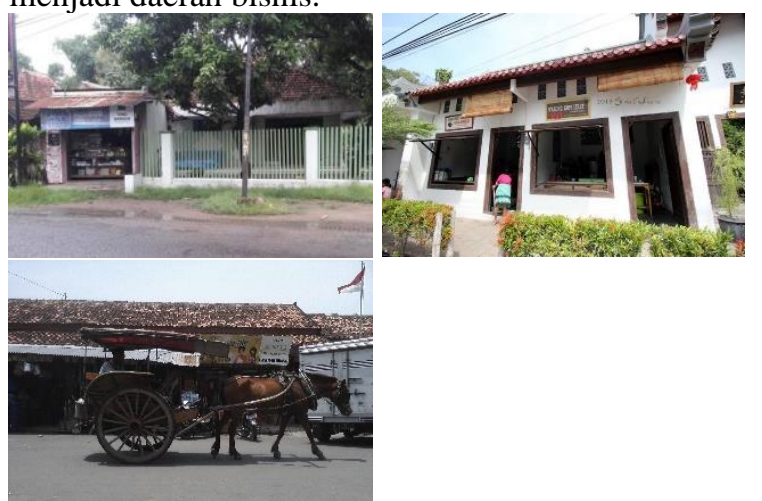

Gambar 35. Kondisi ruko yang memiliki arsitektur Tionghoa-Belanda (Foto Pribadi, 2017)

Munculnya dikotomi sebagai proses pemadatan urbanisasi di pinggiran selatan dan timur kota menjadikan wilayah tegalan yang membentang dari arah timur ke selatan 10 tahun sebelumnya bertransformasi menjadi daerah padat penduduk dengan alun-alun sebagai pusatnya. Sehingga banyak bangunan-bangunan modern muncul dengan arsitektur campuran Tionghoa-BelandaJawa bahkan ada yang meninggalkan arsitektur tradisional.

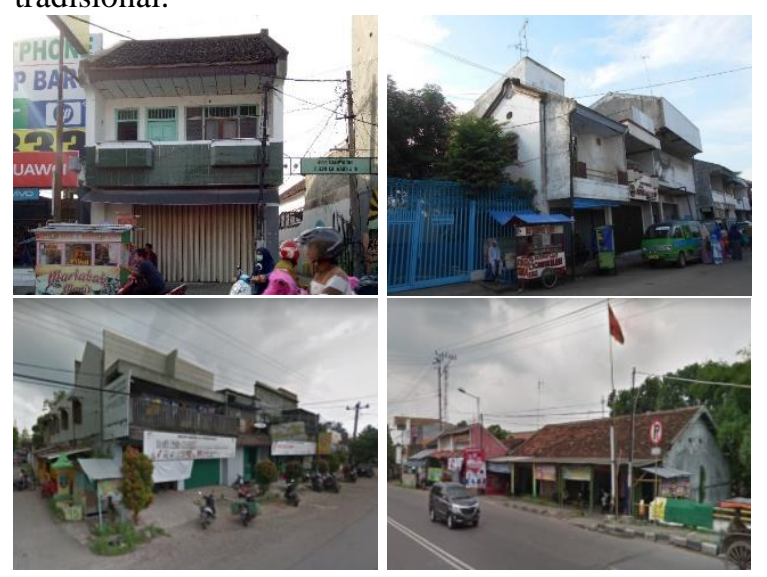

Gambar 36. Transformasi ruko dengan arsitektur campuran (Foto Pribadi, 2017)

\section{Arsitektur Bangunan Tionghoa}

Arsitektur bangunan Tionghoa dalam (RTBL

(Rencana Tata Bangunan dan Lingkungan) Kawasan Pusaka Lasem Kabupaten Rembang, 2017) :

1. Permukiman Tionghoa (gambar 21)

Bangunan rumah yang dimiliki masyarakat Tionghoa sampai saat ini dilestarikan sebagai bangunan heritage yang di istilahkan little china.
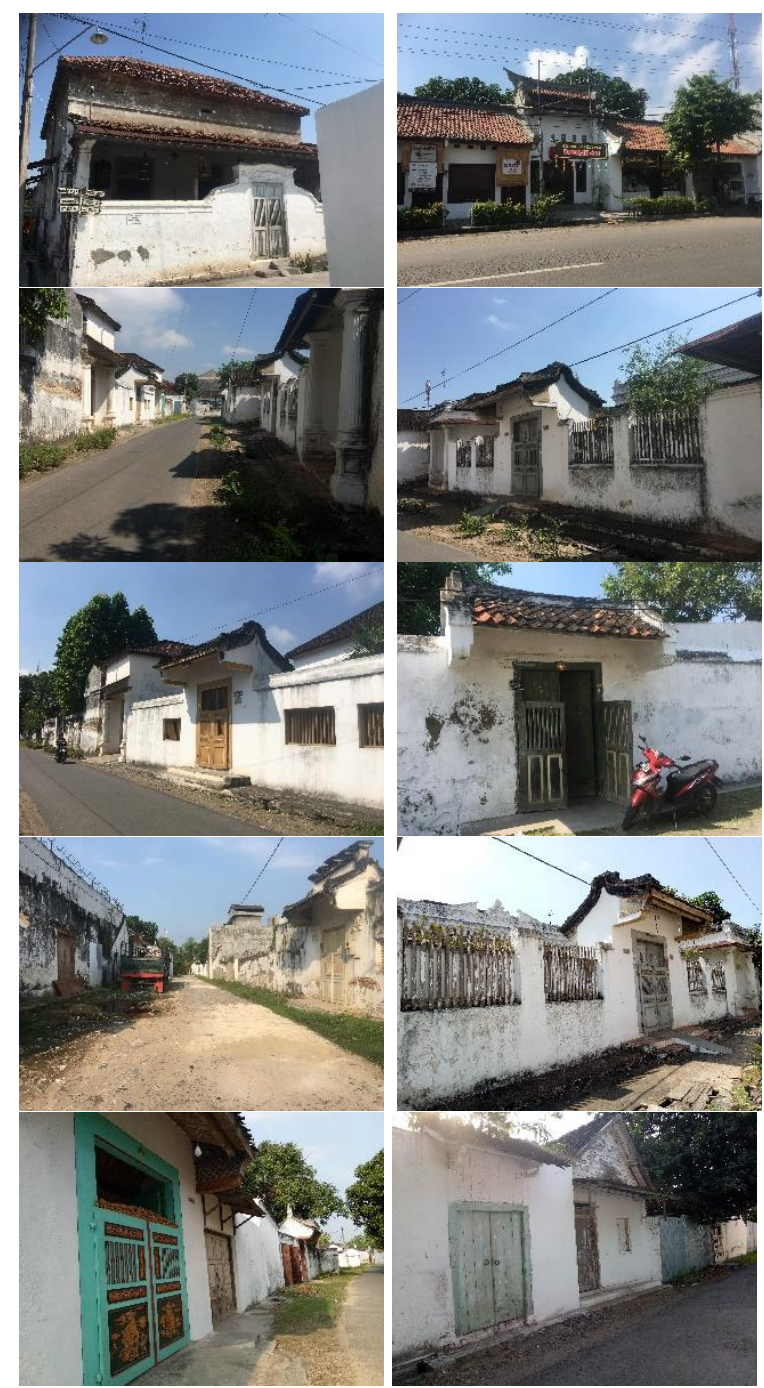

Gambar 37. Bangunan dan lingkungan permukiman Tionghoa di Kota Lasem (Foto Pribadi, 2017)

Gambar diatas menunjukan bahwa rumah-rumah masyarakat Tionghoa sampai saat ini masih difungsikan dan dilestarikan dengan maksimal. Walaupun terdapat beberapa bangunan yang sudah mulai terlihat rusak dan memerlukan perbaikan yang sangat serius. Lingkungan kawasan permukiman tersebut terlihat sangat kental bahkan dengan masih kokohnya pagar yang bercirikhas Tionghoa dan jalan kecil (sempit) menjadikan suasana lebih seperti permukiman pecinan tempo dulu.

2. Bangunan Arsitektur Tionghoa

Selain rumah tinggal terdapat bangunan yang berarsitektur Tionghoa yang dilestarikan antara lain sebagai berikut: Klenteng, Rumah Makan, Pertokoan (perdagangan jasa) dan Bangunan lainnya. 


\section{KESIMPULAN \\ Kesimpulan}

Datangnya etnis Tionghoa di Kota Lasem memberikan pengaruh besar terhadap perkembangan kota, pesatnya perdagangan setelah adanya pembauran etnis Tiongkok dan Pribumi membentuk akulturasi budaya yang sangat kental. Berdasarkan data intensitas di kawasan studi, prosentase permukiman Tionghoa mencapai $133.385 \mathrm{~m}^{2}$ atau $25 \%$ dari total luasan 539.068 $\mathrm{m}^{2}(53,90 \mathrm{Ha})$. Pengaruh masyarakat Tionghoa juga terlihat pada bangunan-bangunan seperti toko-toko, ruko, masjid dan pondok pesantren yang memiliki arsitektur tradisional bangunan Tionghoa yang menyebar di kawasan studi.

\section{Saran}

Jika melihat prosentase luasan dan bentuk bangunan yang masih mempertahankan keasliannya maka diharapakan kawasan permukiman pecinan tersebut dijadikan kawasan heritage pecinan. Sehingga dapat dijadikan kawasan konservasi yang berupa perkotaan berkawasan skala kecil.

Dalam penelitian ini masih banyak yang dapat digali dan diteruskan oleh peneliti lain yang berkaitan dengan kawasan Kota Lasem.

\section{UCAPAN TERIMA KASIH}

Terima kasih saya ucapkan kepada Ibu Suzanna Ratih Sari dan seluruh dosen pasca sarjana Universitas Diponegoro yang telah membantu dalam terlaksana dan terselesaikannya jurnal ini. Semoga jurnal ini dapat bermanfaat bagi semua pihak yang menggunakannya.

\section{DAFTAR PUSTAKA}

Ayuningrum, D. (2019). Akulturasi Budaya Cina Dan Islam Dalam Arsitektur Tempat Ibadah Di Kota Lasem, Jawa Tengah. Sabda: Jurnal Kajian Kebudayaan, $12(2), \quad 122$. https://doi.org/10.14710/sabda.12.2.122-135

Christy, A., \& Setyawan, W. (2016). Pariwisata Heritage sebagai Hasil Reinkarnasi Kawasan Pecinan Surabaya. Jurnal Sains Dan Seni ITS, 5(2), 5-10. https://doi.org/10.12962/j23373520.v5i2.18152

Fatimah, T. (2014). Sejarah Kawasan Pecinan PancoranGlodok Dalam Konteks Lokalitas Kampung Kota Jakarta.

Hendraswati, Nurcahyani, L., \& Listiana, D. (2012). Potret Kampung-Kampung Pendatang di Banjarmasin.

Kartika, T., Fajri, K., \& Robi'al, K. (2017). Pengembangan Wisata Heritage Sebagai Daya Tarik Kota Cimahi. 14(2), 35-46. https://doi.org/10.17509/jurel.v14i2.9102
RTBL (Rencana Tata Bangunan dan Lingkungan) Kawasan Pusaka Lasem Kabupaten Rembang, (2017).

Pratiwo. (2010). Arsitektur Tradisional Tionghoa dan Perkembangan Kota.

Rudiansyah. (2014). Tipologi dan Makna Simbolis Rumah Tjong A Fie di Kota Medan.

Runa, I. W. (2016). Konservasi Bangunan Bersejarah. Jurnal UNDAGI, 1-11. http://repository.warmadewa.ac.id/300/2/JURNA L UNDAGI 2016 KONSERVASI BANGUNAN BERSEJARAH.pdf

Setiawan, L., Astuti, W., \& Rini, E. (2017). Tingkat Kualitas Permukiman (Studi Kasus: Permukiman Sekitar Tambang Galian C Kecamatan Weru, Kabupaten Sukoharjo). 1-11.

Sujana, A. (2017). Adaptasi Bangunan Cagar Budaya Perspektif Indonesia. A083-A090. https://doi.org/10.32315/sem.1.a083

Undang-Undang No. 1 Tahun 2011 Tentang Perumahan dan Kawasan Permukiman, (2011). 